\title{
Fox sightings in a city are related to certain land use classes and sociodemographics: results from a citizen science project
}

\author{
Theresa Walter ${ }^{1,4}$, Richard Zink², Gregor Laaha ${ }^{3}$, Johann G. Zaller ${ }^{4}$ and Florian Heig ${ }^{4^{*}}$ (1)
}

\begin{abstract}
Background: Red foxes (Vulpes vulpes L.) have become successful inhabitants of urban areas in recent years. However, our knowledge about the occurrence, distribution and association with land uses of these urban foxes is poor, partly because many favoured habitats are on private properties and therefore hardly accessible to scientists. We assumed that citizen science, i.e. the involvement of the public, could enable researchers to bridge this information gap. We analysed 1179 fox sightings in the city of Vienna, Austria reported via citizen science projects to examine relationships between foxes and the surrounding land use classes as well as sociodemographic parameters.
\end{abstract}

Results: Conditional probabilities of encountering foxes were substantially higher in gardens, areas with a low building density, parks or squares as compared to agricultural areas, industrial areas or forests. Generalized linear model analyses showed that sociodemographic parameters such as education levels, district area, population density and average household income additionally improved the predictability of fox sightings.

Conclusions: Reports of fox sightings by citizen scientists might help to support the establishment of wildlife management in cities. Additionally, these data could be used to address public health issues in relation with red foxes as they can carry zoonoses that are also dangerous to humans.

Keywords: Public participation, Human-wildlife interaction, Carnivores, Vulpes vulpes, Urban ecosystems, Remote sensing

\section{Background}

Urban areas are increasing worldwide [1], hence, they will become more important for wildlife, especially for small and middle-sized carnivores [2]. For wildlife various potential habitats exist in urban areas including buildings, streets, squares, gardens, parks and other areas all associated with a wide variety of disturbances by humans. These land use classes are used by wildlife in different ways e.g. gardens as resource of food, parks as hiding places or streets for migration. The red fox (Vulpes vulpes L., 1758) is one of the globally most adaptive and widely distributed carnivore species [2]. Until the 1980s,

\footnotetext{
*Correspondence: florian.heigl@boku.ac.at

${ }^{4}$ Institute of Zoology, University of Natural Resources and Life Sciences, Vienna, Gregor Mendel Strasse 33, 1180 Vienna, Austria

Full list of author information is available at the end of the article
}

foxes in urban areas were mainly reported from the United Kingdom, however, since 1985 they are frequently noticed in many other cities in Canada, Australia, Switzerland, Germany, Japan and Austria [2-4, 25, 62]. There are several reasons why urban areas are attractive to foxes [2]. First, there is a high and constant food availability in urban areas. Second, cities provide safety from interspecific competition. Third, urban areas can provide more shelter or den sites compared to rural areas. Fourth, in cities foxes are safe from being hunted as legal regulations usually restrict hunting near houses [5].

Studying fox ecology in urban areas with focus on occurrence, distribution and use of different land use classes is especially important for public authorities when identifying possible risks of human-wildlife conflicts or disease outbreaks. However, despite the increasing trend in urban fox populations there is still little known about 
associations between foxes and surrounding land use classes. The challenges to study urban foxes with common non-invasive monitoring methods like camera trapping, transect sampling or hair sampling are great due to (i) omnipresence of people and dogs, (ii) risk of theft of the exposed research equipment in the public space [68] and (iii) private property and therefore no access for scientists to many urban habitats frequently favoured by animals (e.g., private gardens, industrial areas) $[6,7,9]$. Findings from studies dealing with urban foxes show that home ranges of urban foxes tend to be smaller than home ranges of rural foxes [10] and urban foxes have been shown to being less territorial and more living in family groups than rural foxes due to more stable food abundances (e.g., Bristol 37 individuals $/ \mathrm{km}^{2}$ [11], Melbourne 16 individuals $/ \mathrm{km}^{2}$ [12]; in comparison rural Britain 0.16 to 2.62 individuals $/ \mathrm{km}^{2}$ [13], rural Germany 0.7 to 2.7 individuals $/ \mathrm{km}^{2}$ [14]). For the city of Zurich, Switzerland, analysis of fox stomach contents showed that more than $50 \%$ of an average stomach content was from anthropogenic food resources [15].

The objective of the current study was to test whether a citizen science approach might be suitable to address the above-mentioned challenges regarding research on urban foxes $[6,9,16]$. We define citizen science as scientific research carried out with the aid of interested volunteers [17]. We are aware of the concerns regarding potential biases of citizen science data regarding geographical coverage and data quality. However, in wildlife research, citizen science has a long-standing tradition and is in the meanwhile also scientifically acknowledged $[6,8$, 17]. Despite potential bias in geographic coverage due to unbalanced numbers of participants in some regions of a project or uncertainties in data quality when appropriate quality controls are missing when using citizen science, citizen science can be cost-effective when conducting long term monitoring [18]. Only a few studies address human-carnivore encounters in urban areas $[9,19,20]$. These studies found that wildlife sightings depend on habitat use and activity patterns of wildlife, but also on the use and accessibility of different land use classes by humans, and the visibility of wildlife in different habitats $[19,20]$. It was shown by comparing radio-telemetry data and public sightings of urban coyotes that public sightings overestimated the use of more open vegetation as habitat compared to forests with short sight distances. Public sightings were biased towards habitats where people concentrated and daylight when people are more active, although coyotes were moving greater distances at night [19]. The positive association of coyote encounters with building densities in another study was due to more people being present in these areas and not due to coyotes using these areas more frequently [20]. Additionally, both humans and wildlife show certain activity patterns in their daily life, which may influence wildlife sightings [21].

The aim of the current study was to assess to what extent sightings of urban foxes by citizens are influenced by the surrounding land use and/or sociodemographic parameters. In this study, we define sightings as humanfox encounters which are reported via our citizen science project website. Additionally, we investigated temporal changes over years, months and daytime in urban fox sightings. To the best of our knowledge, our study is the first to use citizen science as a non-invasive method to study urban fox occurrence and distribution on a large scale and to include sociodemographic data as an explanatory variable [20]. Results should (i) help researchers to establish a large-scale monitoring system for urban areas by using a citizen science method, (ii) inform wildlife managers in urban areas on human-fox-encounters and therefore (iii) lay the foundation for future systems to prevent human-wildlife conflicts as well as spreading of fox-related diseases.

\section{Results \\ Urban fox sightings}

A total of 1179 fox sightings were reported between 2010 and 2015. Foxes were observed in every year of the study duration. The exact date of sighting is known for 966 fox sightings. Fox sightings were not equally distributed across months $\left(\mathrm{X}^{2}=171.913, d f=11, \mathrm{P}<0.01\right.$; Fig. 1a). Across years, most fox sightings were reported in July $(n=130)$ the fewest in November $(n=29)$. Foxes in Vienna could be observed at every hour of the day, $41.66 \%$ of the sightings were reported between 9 p.m. and 3 a.m. (Fig. 1b). Fox sightings were not equally distributed across the day $\left(\mathrm{X}^{2}=154.2564, d f=23, \mathrm{P}\right.$-value $\left.<0.01\right)$. Number of fox sightings per grid cell varied from 0 to 18 (Fig. 2a). The overall probability for sighting a fox in Vienna calculated per grid cell was 0.27 . When calculating the conditional probabilities for each land use class, this value was then used as threshold for deciding which land use classes influenced fox sightings positively or negatively.

Conditional probabilities $\mathrm{P}(\mathrm{E} \mid \mathrm{B})$ were calculated for all 58 land use classes (Fig. 2b). All land use classes with $\mathrm{P}>0.27$ are positively associated with fox sightings (Fig. 2b, Table 1), whereas land use classes with $\mathrm{P}<0.27$ are negatively associated with them (Fig. $2 \mathrm{~b}$, Table 2). Land use classes with an increased association of fox sightings accounted for $48.54 \%$ and land use classes with a negative association of fox sightings amounted to $51.46 \%$ of the total research area. Gardens and areas with a low building density, as well as parks and squares are positive associated with fox sightings, whereas 

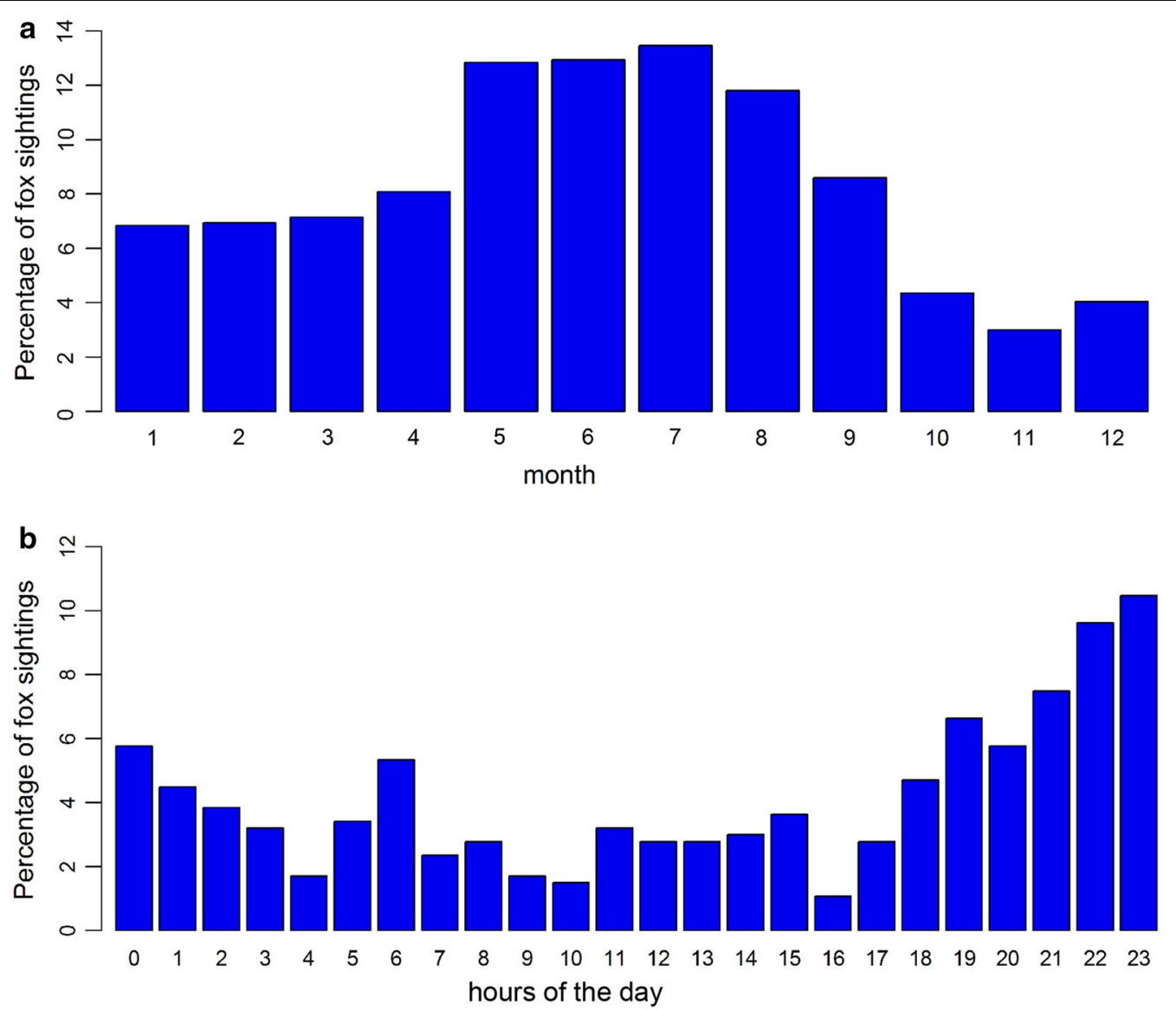

Fig. 1 Fox sightings in the city of Vienna per month $(n=966 ; \mathbf{a})$ and per hour of the day $(n=468 ; \mathbf{b})$ as percentage of total fox sightings between 2010 and 2015

agricultural areas, a diverse range of small other green areas, as well as factory premises and industrial areas and also the forest are negative associated with fox sightings. For some of these land use classes with a negative association of fox sightings, as for instance industrial areas, the relative frequency of fox sightings is rather high compared with others that are positively associated with fox sightings (Tables 1, 2 respectively). However, also the availability of these land use classes is high within the study area, and therefore the probability of fox sightings per land use class is put into perspective by dividing it by $P\left(B_{j}\right)$, thus calculating the conditional probabilities of fox sightings per land use class.

\section{Influencing factors for fox sightings}

Influencing factors for fox sightings were analysed with three different generalised linear models. The model GLM1, containing only percentage of land use classes as predictor variables, showed a highly significant positive influence of different kinds of gardens (detached house gardens, court gardens, allotments), parks and squares on fox sightings, as well as the zoo (Additional file 1: Table S1). Fields, streams, industrial areas and sport fields showed a significant negative influence on human-fox encounters. For this model AIC was 4302.3, Cox and Snell $\mathrm{R}^{2}=0.3084$ and $\mathrm{VIF}<1.5$ for all coefficients, therefore meeting the criterion of not exceeding a VIF of 10 [22]. The model GLM2 containing only sociodemographic influence factors showed a significant influence of the number of people with different education levels per district on reported fox sightings per grid cell (Additional file 2: Table S2). Number of reports of a fox sighting increased with increasing numbers of people with a university degree per district and decreased with increasing numbers of people with a compulsory education as highest level of education, increasing district area and average household income. Population density had no significant influence on reported fox sightings $\left(\mathrm{AIC}=4661.4\right.$, Cox and Snell $\mathrm{R}^{2}=0.18, \mathrm{VIF}<2.8$ for all coefficients).

In model GLM3 percentage of land use classes per grid cell was combined with sociodemographic influence 

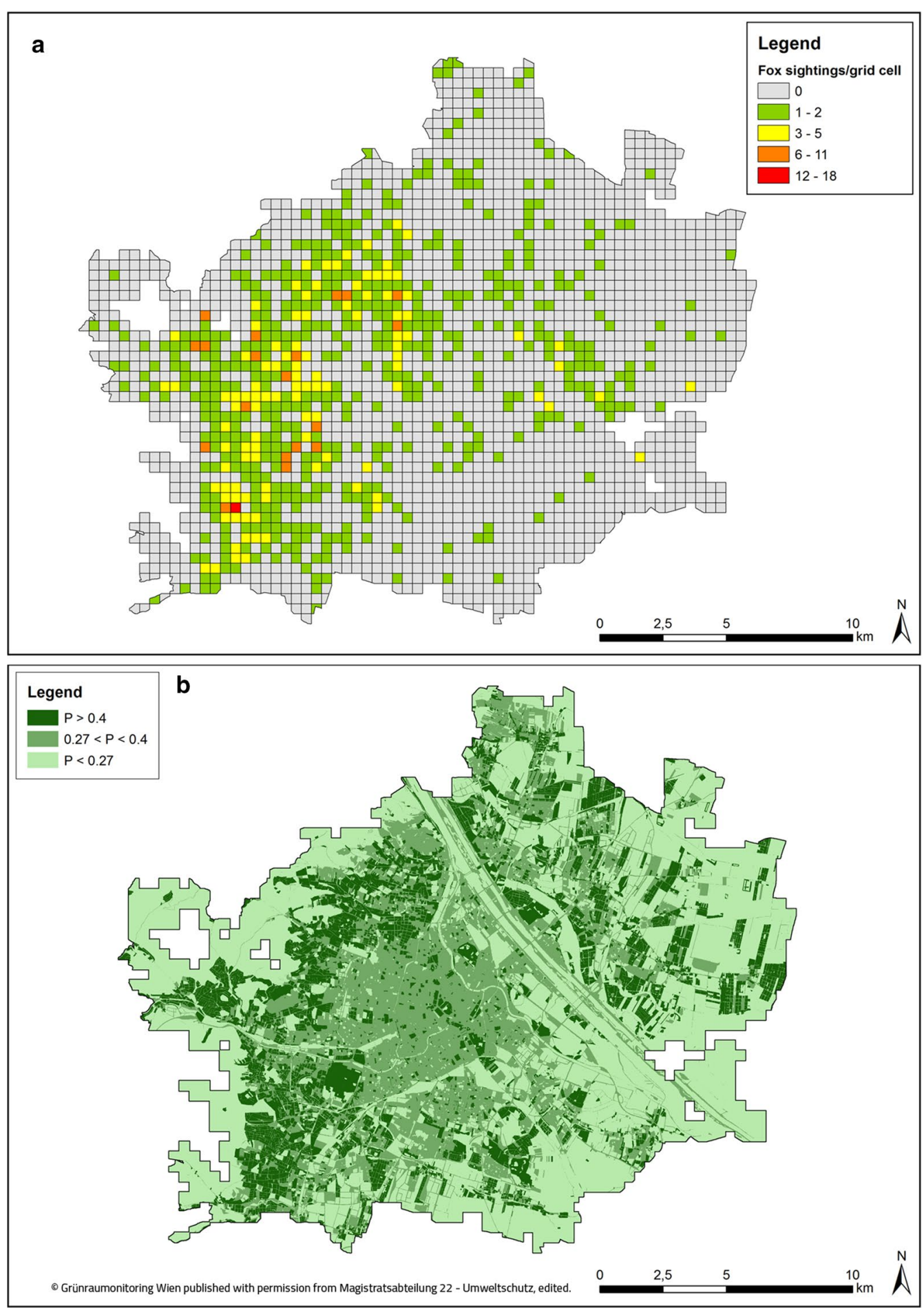

Fig. 2 Number of fox sightings in Vienna between 2010 and 2015 per $400 \times 400$ m grid cell $(n=1179 ;$ a). Map of conditional probabilities (P) of fox sightings for land use classes in Vienna (b). The darker green the area, the higher the values for $P$

factors (Table 3). Positive and negative influence of the different factors on reported fox sightings remained nearly the same, however model fit was improved compared to only considering land use information or sociodemographics (AIC $=4089.9$, Cox and Snell $\mathrm{R}^{2}=0.3701$, VIF $<3.7$ for all coefficients). 
Table 1 Conditional probabilities of fox sightings in Vienna from 2010 to 2015 for all land use classes with a positive association with fox sightings with $P\left(E \mid B_{j}\right)>0.27$

\begin{tabular}{|c|c|c|c|}
\hline Land use class & $P\left(E \cap B_{j}\right)$ & $P\left(B_{j}\right)$ & $P\left(E \mid B_{j}\right)$ \\
\hline Zoo & 0.0003 & 0.0004 & 0.892 \\
\hline Pond & 0.0003 & 0.0004 & 0.647 \\
\hline Leafy property line & 0.0003 & 0.0005 & 0.555 \\
\hline Park & 0.013 & 0.023 & 0.544 \\
\hline Square & 0.0007 & 0.001 & 0.520 \\
\hline Court garden & 0.003 & 0.007 & 0.503 \\
\hline Flowerbed & 0.0007 & 0.001 & 0.487 \\
\hline Not developed property (garden) & 0.0007 & 0.002 & 0.45 \\
\hline Back garden & 0.003 & 0.008 & 0.45 \\
\hline Terrace, roof garden & 0.0001 & 0.0003 & 0.419 \\
\hline Detached house garden & 0.049 & 0.118 & 0.417 \\
\hline Allotment & 0.011 & 0.026 & 0.416 \\
\hline Parking space & 0.0004 & 0.001 & 0.406 \\
\hline Grove & 0.002 & 0.005 & 0.382 \\
\hline Single trees & 0.002 & 0.005 & 0.382 \\
\hline Green area in residential neighbourhood & 0.029 & 0.08 & 0.364 \\
\hline Other land uses & 0.003 & 0.007 & 0.36 \\
\hline Tree line & 0.007 & 0.02 & 0.358 \\
\hline Council housing patio & 0.0004 & 0.001 & 0.352 \\
\hline Alley & 0.004 & 0.012 & 0.35 \\
\hline Other sealed area & 0.0005 & 0.001 & 0.346 \\
\hline Roof area & 0.0002 & 0.0005 & 0.345 \\
\hline Courtyard & 0.003 & 0.007 & 0.345 \\
\hline Roads & 0.016 & 0.048 & 0.334 \\
\hline Recreation area & 0.007 & 0.021 & 0.319 \\
\hline Yard & 0.017 & 0.055 & 0.311 \\
\hline Vineyard & 0.006 & 0.021 & 0.305 \\
\hline Traffic island & 0.004 & 0.012 & 0.287 \\
\hline
\end{tabular}

Land use classes in descending order of $P\left(E \mid B_{\mathrm{j}}\right)$; the higher $P\left(E \mid B_{\mathrm{j}}\right)$, the higher the probability of a fox sighting $P\left(E \cap B_{j}\right)$ is the relative frequency of fox sightings in land use class $B_{j}, P\left(B_{j}\right)$ is its share in the study area

\section{Discussion}

Research in urban wildlife ecology and human-wildlife interactions in cities becomes more important as more and more people live in urban areas $[1,2]$. This is the first study analysing occurrence and distribution of urban fox sightings in relation to land use and sociodemographics in a European city using a citizen science approach. Fox sightings were not equally distributed across the year and over months, $51 \%$ of fox sightings were made between May and August. This could be explained by a fox population peak with many young foxes present and gradually starting to explore greater areas in these months [23]. It should also be considered that the internet platform "StadtWildTiere" was launched and promoted in the public at the end of May and citizens in general are more active outdoors in summer months. Fox sightings were also reported for every hour of the day (Fig. 1). Between 6 p.m. and midnight about $45 \%$ of all reported human-fox encounters took place, whereas between midnight and 6 a.m. only about $22 \%$ of the sightings were reported. This distribution of sightings is most likely a consequence of human behaviour and activity patterns, rather than due to fox activity patterns, since foxes are considered to be mainly active at night [24]. Gloor found that urban foxes in Zurich preferred public parks and other areas closed for humans during the first half of the night and used residential areas more, when human activity was low in these areas in the second half of the night [25]. For foxes in Bristol (UK) it was even shown that they crossed less roads before midnight than after, therefore supposedly adapting their activity patterns to reduce mortality risks by roads and avoiding human activity [26]. Fox sightings were reported throughout all districts of the city. Our analyses that fox sightings are affected by land use classes suggest that foxes prefer certain land use classes [20]. High conditional probabilities were calculated for different types of gardens and areas with a low building density, as well as for parks and squares. Our citizen science data are thus in line with telemetry studies on urban foxes [10, 25]. People also had good access to these land use classes and foxes are well visible, although during the day they tend to rest in vegetative structures [25]. Low conditional probabilities for fox sightings were calculated for agricultural areas, a diverse range of small other green areas, as well as factory premises and industrial areas and also forests. Based on several studies, one would assume that the number of sightings of foxes on these land use classes in Vienna was as high as that of gardens and parks, however several aspects should be considered [27-29]. First, a sighting of a fox on an agricultural field or in the forest within the city borders may not be as special for people, as a sighting in their own garden. Therefore, foxes seen on those land use classes might not be reported as often as foxes seen in gardens or in parks within the city. These results seem to be consistent with other research which found that sampling effort can bias results of citizen science projects [30-32]. Second, visibility of foxes in a forest is likely to be worse than in gardens or parks. Third, access to industrial areas and factory premises was limited to operating hours and to people who have access. There is the possibility, that in our project we might not have had enough citizen scientists with access to these land use classes, thus resulting in low conditional probability values. A special land use class category was the 
Table 2 Conditional probabilities of fox sightings for all land use classes with a negative association with fox sightings with $P\left(E \mid B_{j}\right)<0.27$

\begin{tabular}{llll}
\hline Land use class & $P\left(E \cap B_{j}\right)$ & $P\left(B_{j}\right)$ & $P\left(E \mid B_{j}\right)$ \\
\hline Sport facility & 0.005 & 0.018 & 0.264 \\
Mixed green areas & 0.005 & 0.017 & 0.263 \\
Swimming facility & 0.001 & 0.004 & 0.261 \\
Pavement café & 0.000 & 0.000 & 0.255 \\
Fountain & 0.000 & 0.000 & 0.248 \\
Littoral zone & 0.002 & 0.008 & 0.248 \\
Scrubs and meadows & 0.001 & 0.005 & 0.245 \\
Parking space, camping area & 0.002 & 0.008 & 0.24 \\
Cemetery & 0.004 & 0.015 & 0.237 \\
Nursery garden & 0.000 & 0.0001 & 0.237 \\
Standing waterbody & 0.004 & 0.018 & 0.231 \\
Derelict green space & 0.001 & 0.002 & 0.228 \\
Front garden & 0.001 & 0.004 & 0.221 \\
Railway property, rail track & 0.005 & 0.024 & 0.22 \\
Meadow, shrubs, young stands & 0.007 & 0.03 & 0.217 \\
Play ground, sport facility & 0.001 & 0.003 & 0.215 \\
Relay station & 0.003 & 0.013 & 0.212 \\
Fruit orchard & 0.0001 & 0.0007 & 0.205 \\
Forest & 0.021 & 0.112 & 0.189 \\
Industrial area & 0.013 & 0.074 & 0.178 \\
Fallow land & 0.0008 & 0.005 & 0.174 \\
Agricultural business and nursery & 0.004 & 0.023 & 0.169 \\
Non sealed area & 0.0001 & 0.0005 & 0.142 \\
Unploughed strip & 0.0002 & 0.001 & 0.136 \\
Stream & 0.003 & 0.02 & 0.126 \\
Quarry & 0.0002 & 0.001 & 0.12 \\
Empty lot & 0.0001 & 0.001 & 0.118 \\
Fields & 0.008 & 0.108 & 0.077 \\
Windbreak & 0.000 & 0.001 & 0.016 \\
Noise barrier & 0.000 & 0.0003 & 0.006 \\
Small yard, green dominated & 0.000 & 0.000 & $<0.001$ \\
Plant pot & 0.000 & 0.000 & $<0.001$ \\
\hline Land usectasses in descending & $P(E B)$ & & \\
\hline
\end{tabular}

Land use classes in descending order of $P\left(\mathrm{E}_{\mid} \mathrm{B}_{\mathrm{j}}\right)$; the lower $P\left(\mathrm{E} \mid \mathrm{B}_{\mathrm{j}}\right)$, the lower the probability of a fox sighting. $P\left(E \cap B_{j}\right)$ is the relative frequency of fox sightings in land use class $B_{j}, P\left(B_{j}\right)$ is its share in the study area

zoo, situated in the Schönbrunn castle grounds: while accounting for only $0.04 \%$ of the study area, foxes were reported in two out of three grid cells containing the zoo as land use class, resulting in the highest conditional probability value of all land use classes. Reported fox sightings from the zoo are sightings of a fox family, which is quite famous among Viennese people, roaming the premises of the zoo, and are not animals held in captivity. The last aspect to consider is of course the possibility that no foxes were present in areas with no reported sightings.

Similarly, to the conditional probability results, analyses with GLMs indicated that fox sightings increased with increasing area of private gardens, public parks and squares. This again mirrored habitat use by urban foxes on a large scale like found in various studies on smaller scales using other methods [10, 25, 33, 34]. These land use classes provide easy access for foxes to food resources as well as shelter. Additionally, these land use classes are also preferred by humans, which makes a human-foxencounter more likely. As mentioned above, these results certainly do not indicate that land use classes with no fox sightings, inhabit no foxes. It might also be that nonreports from these land use classes originated in human perception of the land use classes as 'not urban', therefore not worthy to report a fox sighting to a project on urban wildlife. This is similar to other studies which refer to 'reporting bias' in citizen science projects $[35,36]$. The GLM containing only sociodemographic predictor variables showed that education level is highly significant, which indicates that people with a university degree reported fox sightings more often than people with only a compulsory education. Since citizen science in general is not restricted to higher educated people [37], this result can be interpreted in a way that our project promotion was focused on the target group of people interested in wildlife. However, the result is also in line with previous findings showing that some citizen science projects seem to be more attractive to people with higher education (e.g. [38]). This challenge of reaching a broad target audience to avoid bias in data collection in citizen science projects could be addressed by training observers with different educational backgrounds or reaching a broader audience through different public relation activities. However, the problem of reaching a broad audience is existing in science communication as well, is multi-facetted and can only be solved by many parallel activities by scientists, communicators, politicians and NGOs. As expected, district area showed no significant influence on explaining fox sightings and human population density did not remain within the model after a stepwise AIC was performed.

Data quality is a core issue of every scientific research project, especially when citizen scientists are involved [39-44]. More than $60 \%$ of the sightings were submitted by citizen scientists without a photo for proof. Nevertheless, we considered submissions without a photo of the reported fox sighting to be sufficient, as the red fox is a well-known species and not easily confused with any other wildlife species living in Vienna. In citizen science projects, variation in observer quality and variation in sampling effort over time and space often pose challenges 


\begin{tabular}{|c|c|c|c|c|}
\hline & Estimate & Std. error & $z$ value & $\operatorname{Pr}(>|z|)$ \\
\hline Detached house garden & 1.749 & $1.44 \mathrm{e}-01$ & 12.161 & $<0.001$ \\
\hline Edu_compulsory & $-5.55 e-05$ & $4.28 \mathrm{e}-06$ & -12.952 & $<0.001$ \\
\hline Park & 1.900 & $2.12 \mathrm{e}-01$ & 8.957 & $<0.001$ \\
\hline Fields & -1.855 & $3.73 e-01$ & -4.973 & $<0.001$ \\
\hline Forest & $-7.73 e-01$ & $1.68 \mathrm{e}-01$ & -4.604 & $<0.001$ \\
\hline Industrial area & -1.128 & $3.06 \mathrm{e}-01$ & -3.686 & $<0.001$ \\
\hline Stream & -3.795 & $7.38 \mathrm{e}-01$ & -5.145 & $<0.001$ \\
\hline Recreation area & 3.515 & $3.94 \mathrm{e}-01$ & 8.928 & $<0.001$ \\
\hline Ave_income & $-7.28 \mathrm{e}-05$ & $1.46 \mathrm{e}-05$ & -4.998 & $<0.001$ \\
\hline Edu_university & $5.2 \mathrm{e}-05$ & $1.28 \mathrm{e}-05$ & 4.052 & $<0.001$ \\
\hline Allotment & 1.577 & $2.93 e-01$ & 5.379 & $<0.001$ \\
\hline Tree row & 3.540 & 1.03 & 3.436 & $<0.001$ \\
\hline Zoo & 3.151 & $8.22 \mathrm{e}-01$ & 3.835 & $<0.001$ \\
\hline Court garden & 1.982 & $6.65 e-01$ & 2.983 & 0.003 \\
\hline Leafy property line & 5.170 & 1.907 & 2.711 & 0.007 \\
\hline Pond & 5.999 & 2.273 & 2.639 & 0.008 \\
\hline District_area & $-1.84 \mathrm{e}-05$ & $1.15 e-05$ & -1.610 & 0.107 \\
\hline Single trees & 4.032 & 2.520 & 1.600 & 0.11 \\
\hline
\end{tabular}

for data analysis [41, 45-47]. Including observer characteristics in statistical analysis can account for variation in data sets gathered by citizen scientists [21, 48]. In our study the combination of land use classes and sociodemographic data lead to a better model than just land use classes. When lacking information on the knowledge of every single observer, sociodemographic census data have been shown to be an important source of variation in citizen science data [20]. Additionally, $20 \%$ of the fox sightings were made in private gardens and other forms of private properties, which would be hard to access for researchers [9]. Therefore, citizen science proofed to be a feasible method to research urban foxes.

Citizen science adds different research possibilities to mammal monitoring in urban areas compared to more traditional monitoring methods like camera trapping and transect monitoring. A citizen science approach to wildlife monitoring is appropriate when interactions with wildlife are central to the research question [9]. This can be of high interest when working in urban areas, as human-wildlife contact is increased in certain areas of cities [49]. When researching urban wildlife, the success of a citizen science project can be affected by the species studied. The red fox is a charismatic well-known species and therefore a suited study model. However, even for urban rats, a species not liked by many people, citizen science is nowadays considered as a research method
[50]. Additionally, a new possibility of comparing data from different cities arises, when data on wildlife sightings is gathered through the same project design as it is currently done within the project "StadtWildTiere" in Zurich (Switzerland), Berlin (Germany) and Vienna (Austria). Our findings could also have implications for wildlife management in cities or public health issues. For red foxes in Central Europe, infection with and zoonotic transmission of the Fox tapeworm (Echinococcus multilocularis) is already of interest for urban areas [51-54]. Human-wildlife interactions affect red fox populations as well as predation rate of the infected intermediate hosts of E. multilocularis and should therefore be considered in management strategies of this disease [55].

\section{Conclusions}

Despite common reservations against citizen science as a method, our study demonstrated that these can be partly overcome by including sociodemographic factors in the analyses. Taking the results of this study as basis for future citizen science projects in urban areas, we recommend to develop advanced citizen science projects with a broad focus on various target groups to foster the reporting of fox sightings on a large scale. The mostly positive feeling associated with a personal observation of wildlife in the city during a citizen science project could be followed by a more relaxed coexistence of humans and animals in the cities in general. Additionally, such projects would have the potential to predict the likelihood of human-fox encounters in different places of the city to inform public authorities on possible wildlife conflict areas and public health issues.

\section{Methods}

The current study uses data from the citizen science project "Wildtiere in Wien" (translated "wildlife in Vienna") running from 2010 until May 2015, and its follow-up project "StadtWildTiere" (translated "urban wildlife"; http:// www.stadtwildtiere.at). The citizen science projects were conducted in Vienna, the capital city of Austria, with a total area of $414.87 \mathrm{~km}^{2}$ and about 1.8 million inhabitants in 2015 (Fig. 3). Vienna is surrounded by the Viennese forest in the west, the agricultural plains of the Marchfeld to the northeast, the floodplains of the Lobau to the east, and the Viennese Basin to the south. Green areas (e.g. forests, agricultural areas, parks) make up $45.1 \%$ of the city area, $35.8 \%$ are building areas, $14.4 \%$ traffic areas (e.g. roads, railway tracks), the remaining $4.7 \%$ of the area are water bodies. The percentage of green area varies between 2 and $15 \%$ in the inner districts and can reach up to $70 \%$ in the districts at the fringe of the city. The green spaces are well connected on the city edges and rather patchy in the centre, however a diverse range 


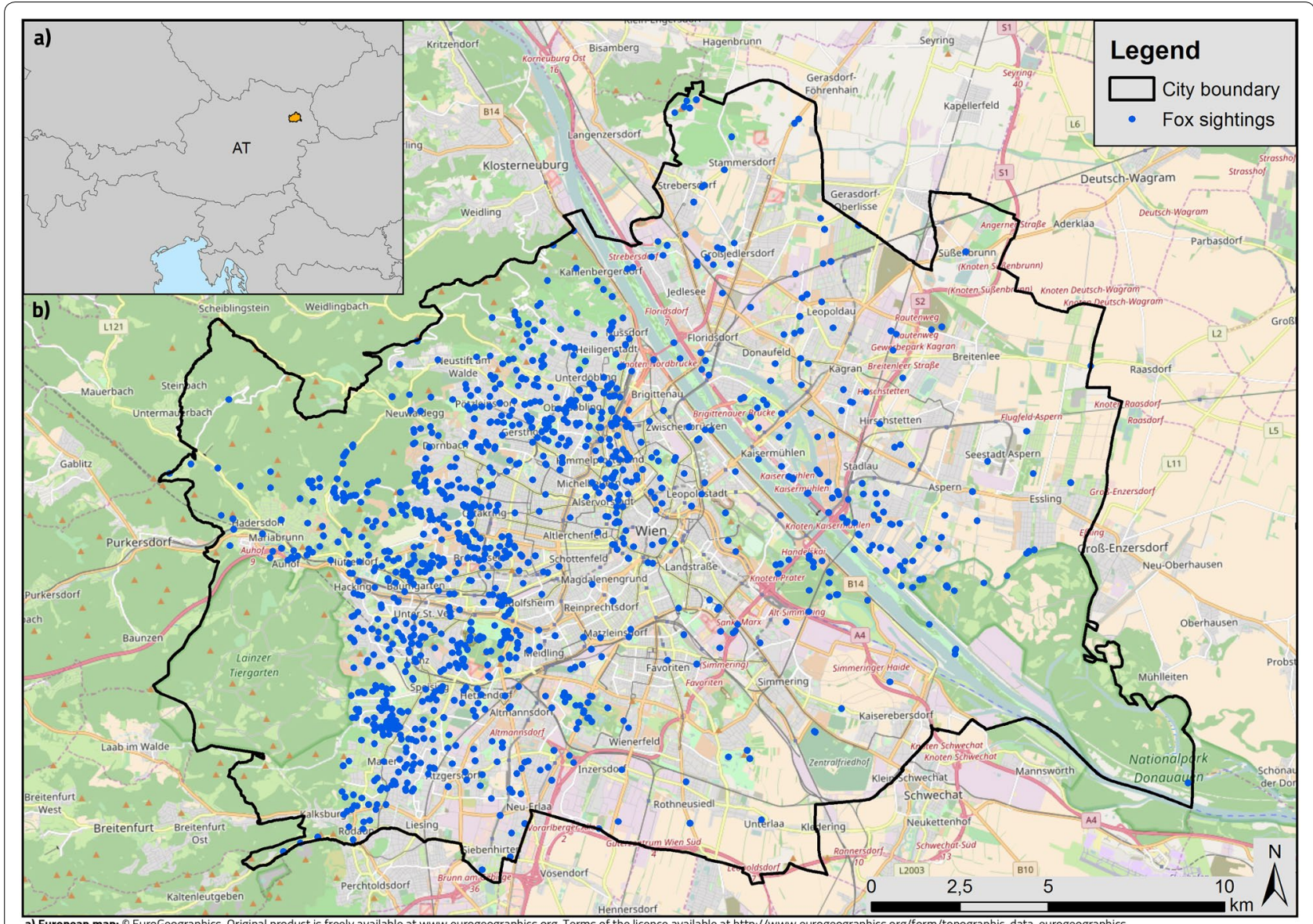

a) European map: $\odot$ EuroGeographics. Original product is freely available at wWw. eurogeographics.org. Terms of the licence available at http:///www.
b) Vienna: $\odot$ OpenStreetMap contributors www.openstreetmap.org CC BY-SA, City Boundary: MA41 - Stadtvermessung ww.data.gv.at CC BY 3.0 AT

Fig. 3 Location of the study area (a). Fox sightings reported between 2010 and $2015(n=1179 ; \mathbf{b})$

of rivers and train tracks connects green areas throughout the city [56]. Since the outskirts of Vienna are rural dominated, the actual research area was not defined by the political border of the city of Vienna, but by all buildings in Vienna surrounded by a $400 \mathrm{~m}$ buffer within a connected area, resulting in a 36,594 ha research area.

\section{Data collection and verification}

In the first citizen science project "Wildtiere in Wien", fox sightings were reported by citizens via phone calls, emails, an online questionnaire on the Research Institute of Wildlife Ecology (FIWI) homepage, or at public information days. Through this project 641 sightings were gathered. All of those sightings included information on the species sighted, concerning the date at least the year it was sighted and the location of the sighting. The follow-up project "StadtWildTiere" pursued additional goals and also enabled us to gather more information about wildlife sightings. However, species, date and location are properties of a dataset which were collected in both projects. On the project website citizen scientists are informed about different wildlife species, where animals can be seen, how they can be supported and how conflicts should be managed. The main part of this online platform is designed for easy data entry of wildlife sightings by citizen scientists. Registration is not mandatory to enter data. Different information on sightings is gathered which includes location (either by address or by pinning a point on an implemented Google Map [57]), animal species, number of individuals, date and time of sighting and different kinds of evidence for the presence of an animal (feeding traces, trace mark, scats, den/ nest, call, trace marks in snow). Up to three photos can be uploaded for each reported sighting. Location, species and date is mandatory, all other information including photo upload is not mandatory. From 27 May until 15 September 2015, 350 fox sightings were reported via the online form. In addition to citizen science data, we included 188 fox carcasses reported by a service provided by the city of Vienna, which collects animal carcasses (ebs Wien Tierservice, Vienna, Austria). After checking all reports for plausibility and deleting entries due to 
obvious mistakes in data entry, we used 1179 reports of fox sightings for our analyses. From these reports, 29.5\% of the sightings were either documented by a photo or a fox carcass that was found; scientists reported $5.7 \%$ of all sightings; $64.8 \%$ of the sightings were reported without a photo. We considered reports without a photo sufficient, as the red fox is a well-known species not easily confused with any other wildlife species living in Vienna.

\section{Remote sensing data}

The fox sightings were processed using the geographic information system ArcGIS (ESRI ArcGIS 10.2.2) [58]. Vienna's political borders and district borders were obtained from the platform Open Data Austria [59]. Habitat descriptions were based on 58 land use classes from the official green space monitoring Vienna (Grünraummonitoring Wien). These classes are distinguished due to their vegetation and their potential to serve as a habitat for animals, plants and humans $[60,61]$. The land use polygons were intersected with a $400 \mathrm{~m} \times 400 \mathrm{~m}$ grid (16 ha) corresponding to the approximate home range of urban foxes calculated for Zurich, Switzerland [25], to obtain land use fractions of possible fox habitats. Zurich was chosen as a reference due to availability of home range data for urban foxes in Central Europe, as well as for similar amount of green spaces in the city and similar lifestyle of people. Overall, the known home ranges of foxes in urban areas vary considerably between seasons, sexes and across the world; individual home ranges range from 5.5 to 70 ha $[10,12,62]$.

\section{Sociodemographic influences}

Sociodemographic census data on the population of Vienna provided and collected by the city of Vienna and the Austrian governmental statistics agency "Statistik Austria", was used to analyse sociodemographic influence factors on fox sightings [63]. Sociodemographic characteristics were available on a district basis. Vienna's 23 districts have areas ranging from 109 ha to 10,231 ha and a population varying between 16,339 and 189,713 inhabitants [56]. Therefore, each grid cell was assigned to a political district of Vienna according to its position. When grid cells were bordering two or more districts, they were assigned to the district in which most of the grid cell area was located. The sociodemographic characteristics used were: district area (District_area), population density (Population_density), number of people with no more than a compulsory education (Edu_compulsory), number of people with a university degree (Edu_university) and average household income (Ave_income). District area was considered to check for a size-effect, thus whether more foxes would simply be seen in districts with a bigger area. Population density accounted for different degrees of urbanisation (districts with low population density have a more rural character, contrary to highly populated districts with plenty of sealed surfaces) or for an effect of quantity (whether the number of people living in an area would explain the number of fox sightings). The two education levels were included to test whether level of education had an influence on reporting. Finally, a relationship between average household income and vegetation cover in urban areas was suggested by many studies (see [20]), so we tested if the average household income has an influence on fox sightings in Vienna.

\section{Statistical analyses}

For analysing when and where foxes were observed in Vienna the distribution of the fox sightings was analysed according to years, months, and time of day using Chi squared tests.

We subsequently calculated empirical conditional probabilities to analyse the degree to which each land use class is associated with fox sightings [64]. Probabilities of fox sightings on land use classes depend on the size of the area of each land use class. Therefore, it is important to be able to calculate probabilities independently from area sizes. This is done by calculating conditional probabilities through dividing probabilities by the relative share of each land use class in the whole study area. For each land use class $B_{j}$, the i subareas $A_{i j}$ of grid cells with sightings (event E) were determined. The conditional probability $\mathrm{P}\left(\mathrm{E} \mid \mathrm{B}_{\mathrm{j}}\right)$ of observing a fox on a specific land use class $\mathrm{B}_{j}$ is then defined as the sum of areal fractions of class $B_{j}$ of cells with sightings:

$$
P\left(E \mid B_{j}\right)=\frac{P\left(E \cap B_{j}\right)}{P\left(B_{j}\right)}=\frac{\sum_{i}\left(A_{i j} / A_{t o t}\right)}{P\left(B_{j}\right)}
$$

where $P\left(E \cap B_{j}\right)$ is the relative frequency of fox sightings in land use class $B_{j}, P\left(B_{j}\right)$ is its share in the study area, $\sum_{i}\left(A_{i j} / A_{\text {tot }}\right)$ is the sum of areal fractions of class $B_{j}$ in cells with sightings, and $A_{t o t}$ the total area under investigation. The conditional probabilities $P\left(E \mid B_{j}\right)$ were finally compared to the overall probability $P(E)$ of grid cells having a fox sighting in order to conclude which land use classes favor or hamper fox sightings.

To analyze which factors influence fox observations three different generalized linear models (GLMs) with Poisson-distribution were employed [65, 66]. GLM1 had only the percentage of each land use class per grid cell as predictor variables, GLM2 had only sociodemographic values as predictor variables and GLM3 had both percentage of each land use class per grid cell and sociodemographic values as predictors. Stepwise variable selection based on the akaike information criterion 
(AIC) was used to find the best fitting models. Cox and Snell $\mathrm{R}^{2}$ was calculated as generalized coefficient of determination, and variance inflation factors (VIF) were calculated to assess for multicollinearity of predictor variables of each model. As a rule, VIF for all predictor variables in a model should be less than 10 [22]. All analyses were performed using statistical software R 3.2.1 [67].

\section{Additional files}

Additional file 1: Table S1. Model-averaged coefficients of the generalised linear model $\mathrm{M} 1$ containing only land use classes as explanatory variables that influence fox sightings in the city of Vienna, Austria.

Additional file 2: Table S2. Model-averaged coefficients of the generalised linear model M2 containing only sociodemographic values as explanatory variables on fox sightings in the city of Vienna, Austria.

\section{Abbreviations}

AIC: akaike information criterion; FIWI: Research Institute of Wildlife Ecology; GLM: generalized linear models; VIF: variance inflation factors.

\section{Authors' contributions}

TW, RZ, FH and JGZ conceived and designed the study; TW and RZ performed the study; TW and GL analysed the data; TW, FH and JGZ wrote the paper. All authors read and approved the final manuscript.

\section{Author details}

${ }_{1}^{1}$ Research Institute of Wildlife Ecology, University of Veterinary Medicine, Vienna, Savoyenstrasse 1, 1160 Vienna, Austria. ${ }^{2}$ Austrian Ornithological Centre, Konrad Lorenz Institute of Ethology, University of Veterinary Medicine, Vienna, Savoyenstrasse 1a, 1160 Vienna, Austria. ${ }^{3}$ Institute for Applied Statistics and Computing, University of Natural Resources and Life Sciences, Vienna, Peter Jordan-Strasse 82, 1190 Vienna, Austria. ${ }^{4}$ Institute of Zoology, University of Natural Resources and Life Sciences, Vienna, Gregor Mendel Strasse 33, 1180 Vienna, Austria.

\section{Acknowledgements}

We are very grateful to all Citizen Scientists who reported their fox sightings for this study. We would like to thank F. Suppan for his assistance in the GIS analysis. We are grateful to the city of Vienna (MA22) for providing us with the data of the greenspace monitoring and the ebs Tierservice Wien for providing us the data on collected fox carcasses.

\section{Competing interests}

The authors declare that they have no competing interests.

\section{Availability of data and materials}

The data that support the findings of this study are available from Magistratsabteilung 22-Umweltschutz, Stadt Wien but restrictions apply to the availability of these data, which were used under license for the current study, and so are not publicly available. In order to protect animals, data on fox sightings generated and analysed are not publicly available either. However, the authors share information upon reasonable request.

\section{Consent for publication}

Not applicable.

Ethics approval and consent to participate Not applicable.

\section{Funding}

The development and running costs of the online platform http://www.stadt wildtiere.at was funded by the association "Entdecke \& Bewahre Natur (EBN)". In addition to funding, EBN did not influence the process of the study.

\section{Publisher's Note}

Springer Nature remains neutral with regard to jurisdictional claims in published maps and institutional affiliations.

Received: 6 July 2018 Accepted: 21 November 2018

Published online: 29 November 2018

\section{References}

1. United Nations, Department of Economic and Social Affairs, Population Division. World Urbanization Prospects: the revision, highlights. United Nations: New York; 2014. p. 2014.

2. Bateman PW, Fleming PA. Big city life: carnivores in urban environments. J Zool. 2012;287:1-23.

3. Ikeda T, Yoshimura M, Onoyama K, Oku Y, Nonaka N, Katakura K. Where to deliver baits for deworming urban red foxes for Echinococcus multilocularis control: new protocol for micro-habitat modeling of fox denning requirements. Parasit Vectors. 2014;7:357.

4. Börner K. Untersuchungen zur Raumnutzung des Rotfuchses, Vulpes vulpes (L., 1758), in verschieden anthropogen beeinflussten Lebensräumen Berlins und Brandenburgs. Humboldt - Universität zu Berlin; 2014.

5. Presse- und Informationsdienst (Magistratsabteilung 53). Gesetz über die Regelung des Jagdwesens (Wiener Jagdgesetz). 2013. https://www.wien. gv.at/recht/landesrecht-wien/rechtsvorschriften/html/19200000.htm. Accessed 27 Oct 2017.

6. Lepczyk CA, Mertig AG, Liu J. Assessing landowner activities related to birds across rural-to-urban landscapes. Environ Manage. 2004;33:110-25.

7. Colding J, Lundberg J, Folke C. Incorporating green-area user groups in urban ecosystem management. AMBIO J Hum Environ. 2006;35:237-44.

8. Cohn JP. Citizen science: can volunteers do real research? Bioscience. 2008;58:192.

9. Weckel ME, Mack D, Nagy C, Christie R, Wincorn A. Using citizen science to map human-coyote interaction in suburban New York, USA. J Wildl Manag. 2010;74:1163-71.

10. Adkins CA, Stott P. Home ranges, movements and habitat associations of red foxes Vulpes vulpes in suburban Toronto, Ontario, Canada. J Zool. 1998;244:335-46.

11. Baker PJ, Funk SM, Harris S, White PCL. Flexible spatial organization of urban foxes, Vulpes vulpes, before and during an outbreak of sarcoptic mange. Anim Behav. 2000;59:127-46.

12. White PCL, Saunders G, Harris S. Spatio-temporal patterns of home range use by foxes (Vulpes vulpes) in urban environments. J Anim Ecol. 1996;65:121-5.

13. Heydon MJ, Reynolds JC, Short MJ. Variation in abundance of foxes (Vulpes vulpes) between three regions of rural Britain, in relation to landscape and other variables. J Zool. 2000;251:253-64.

14. Keuling O, Greiser G, Grauer A, Strauß E, Bartel-Steinbach M, Klein R, et al. The German wildlife information system (WILD): population densities and den use of red foxes (Vulpes vulpes) and badgers (Meles meles) during 2003-2007 in Germany. Eur J Wildl Res. 2011;57:95-105.

15. Contesse P, Hegglin D, Gloor S, Bontadina F, Deplazes P. The diet of urban foxes (Vulpes vulpes) and the availability of anthropogenic food in the city of Zurich, Switzerland. Mamm Biol. 2004;69:81-95.

16. Dickinson JL, Zuckerberg B, Bonter DN. Citizen science as an ecological research tool: challenges and benefits. Annu Rev Ecol Evol Syst. 2010;41:149-72.

17. Silvertown J. A new dawn for citizen science. Trends Ecol Evol. 2009:24:467-71.

18. Bonney R, Cooper CB, Dickinson J, Kelling S, Phillips T, Rosenberg KV, et al. Citizen science: a developing tool for expanding science knowledge and scientific literacy. Bioscience. 2009;59:977-84.

19. Quinn T. Using public sighting information to investigate coyote use of urban habitat. J Wild Manag. 1995;59:238-45. 
20. Wine S, Gagné SA, Meentemeyer RK. Understanding human-coyote encounters in urban ecosystems using citizen science data: what do socioeconomics tell us? Environ Manage. 2015;55:159-70.

21. Heigl F, Stretz RC, Steiner W, Suppan F, Bauer T, Laaha G, et al. Comparing road-kill datasets from hunters and citizen scientists in a landscape context. Remote Sens. 2016:8:832.

22. Kutner MH, Nachtsheim CJ, Dr JN. Applied linear regression models, 4th edition with student CD. 4th ed. Boston: McGraw-Hill Education; 2004.

23. Robertson C, Baker P, Harris S. Ranging behaviour of juvenile red foxes and its implications for management. Acta Theriol Warsz. 2000;45:525-35.

24. Doncaster CP, Macdonald DW. Activity patterns and interactions of red foxes (Vulpes vulpes) in Oxford city. J Zool. 1997;241:73-87.

25. Gloor S. The rise of urban foxes (Vulpes vulpes) in Switzerland and ecological and parasitological aspects of a fox population in the recently colonised city of Zürich. Dissertation. University of Zurich; 2002.

26. Baker PJ, Dowding CV, Molony SE, White PCL, Harris S. Activity patterns of urban red foxes (Vulpes vulpes) reduce the risk of traffic-induced mortality. Behav Ecol. 2007;18:716-24.

27. Etten WK, Wilson KR, Crabtree RL. Habitat use of red foxes in yellowstone national park based on snow tracking and telemetry. J Mammal. 2007;88:1498-507.

28. Goldyn B, Hromada M, Surmacki A, Tryjanowski P. Habitat use and diet of the red fox Vulpes vulpes in an agricultural landscape in Poland. Z Für Jagdwiss. 2003;49:191-200.

29. Janko C, Schröder W, Linke S, König A. Space use and resting site selection of red foxes (Vulpes vulpes) living near villages and small towns in Southern Germany. Acta Theriol (Warsz). 2012;57:245-50.

30. Zuckerberg B, McGarigal K. Widening the circle of investigation-the interface between citizen science and landscape ecology. Citizen science public participation in environmental research. Ithaca: Cornell University Press; 2012.

31. Lakeman-Fraser P, Gosling L, Moffat AJ, West SE, Fradera R, Davies L, et al. To have your citizen science cake and eat it? Delivering research and outreach through Open Air Laboratories (OPAL). BMC Ecol. 2016;16:57-70.

32. Fink D, Hochachka WM. Using data mining to discover biological patterns in citizen science observations. Citizen science: public participation in environmental research. Ithaca, New York: Cornell University Press; 2012. p. $125-38$.

33. Harris S, Rayner JMV. Urban fox (Vulpes vulpes) population estimates and habitat requirements in several British cities. J Anim Ecol. 1986;55:575-91.

34. Scott DM, Berg MJ, Tolhurst BA, Chauvenet ALM, Smith GC, Neaves K, et al. Changes in the distribution of red foxes (Vulpes vulpes) in urban areas in great Britain: findings and limitations of a media-driven nationwide survey. PLoS ONE. 2014;9:e99059.

35. Isaac NJB, van Strien AJ, August TA, de Zeeuw MP, Roy DB. Statistics for citizen science: extracting signals of change from noisy ecological data. Methods Ecol Evol. 2014;5:1052-60.

36. van Strien AJ, van Swaay CAM, Termaat T. Opportunistic citizen science data of animal species produce reliable estimates of distribution trends if analysed with occupancy models. J Appl Ecol. 2013;50:1450-8.

37. Miller-Rushing A, Primack R, Bonney R. The history of public participation in ecological research. Front Ecol Environ. 2012;10:285-90.

38. Evans C, Abrams E, Reitsma R, Roux K, Salmonsen L, Marra PP. The neighborhood nestwatch program: participant outcomes of a citizen-science ecological research project. Conserv Biol. 2005;19:589-94.

39. van der Velde T, Milton DA, Lawson TJ, Wilcox C, Lansdell M, Davis G, et al. Comparison of marine debris data collected by researchers and citizen scientists: is citizen science data worth the effort? Biol Conserv. 2017;208:127-38.

40. MacKenzie CM, Murray G, Primack R, Weihrauch D. Lessons from citizen science: assessing volunteer-collected plant phenology data with Mountain Watch. Biol Conserv. 2017;208:121-6.

41. Burgess HK, DeBey LB, Froehlich HE, Schmidt N, Theobald EJ, Ettinger AK, et al. The science of citizen science: exploring barriers to use as a primary research tool. Biol Conserv. 2017;208:113-20.

42. Kosmala M, Wiggins A, Swanson A, Simmons B. Assessing data quality in citizen science. Front Ecol Environ. 2016;14:551-60.
43. Lewandowski $\mathrm{E}$, Specht $\mathrm{H}$. Influence of volunteer and project characteristics on data quality of biological surveys. Conserv Biol. 2015;29:713-23.

44. Hunter J, Alabri A, van Ingen C. Assessing the quality and trustworthiness of citizen science data. Concurr Comput-Pract Exp. 2013;25:454-66.

45. Sullivan BL, Aycrigg JL, Barry JH, Bonney RE, Bruns N, Cooper CB, et al. The eBird enterprise: an integrated approach to development and application of citizen science. Biol Conserv. 2014:169:31-40.

46. Le Rest K, Pinaud D, Bretagnolle V. Volunteer-based surveys offer enhanced opportunities for biodiversity monitoring across broad spatial extent. Ecol Inform. 2015;30:313-7.

47. Gonsamo A, D'Odorico P. Citizen science: best practices to remove observer bias in trend analysis. Int J Biometeorol. 2014;58:2159-63.

48. Newman C, Buesching CD, Macdonald DW. Validating mammal monitoring methods and assessing the performance of volunteers in wildlife conservation-"Sed quis custodiet ipsos custodies?". Biol Conserv. 2003;113:189-97.

49. Kretser HE, Sullivan PJ, Knuth BA. Housing density as an indicator of spatial patterns of reported human-wildlife interactions in Northern New York. Landsc Urban Plan. 2008;84:282-92.

50. Desvars-Larrive A, Baldi M, Walter T, Zink R, Walzer C. Brown rats (Rattus norvegicus) in urban ecosystems: are the constraints related to fieldwork a limit to their study? Urban Ecosyst. 2018;21:951-64.

51. Deplazes P, Hegglin D, Gloor S, Romig T. Wilderness in the city: the urbanization of Echinococcus multilocularis. Trends Parasitol. 2004;20:77-84.

52. König A, Romig T. Fox tapeworm Echinococcus multilocularis, an underestimated threat: a model for estimating risk of contact. Wildl Biol. 2010:16:258-66.

53. Brochier B, De Blander H, Hanosset R, Berkvens D, Losson B, Saegerman C. Echinococcus multilocularis and Toxocara canis in urban red foxes (Vulpes vulpes) in Brussels, Belgium. Prev Vet Med. 2007;80:65-73.

54. Robardet E, Giraudoux P, Caillot C, Augot D, Boue F, Barrat J. Fox defecation behaviour in relation to spatial distribution of voles in an urbanised area: an increasing risk of transmission of Echinococcus multilocularis? Int J Parasitol. 2011;41:145-54.

55. Hegglin D, Bontadina F, Deplazes P. Human-wildlife interactions and zoonotic transmission of Echinococcus multilocularis. Trends Parasitol. 2015;31:167-73.

56. Magistratsabteilung der Stadt Wien MA 23-Wirtschaft, Arbeit und Statistik. Statistisches Jahrbuch der Stadt Wien 2015. Vienna, Austria; 2015.

57. Google LLC. Google Maps. Google Maps. 2018. https://www.google.at/ maps/. Accessed 26 Feb 2018.

58. ESRI. ArcGIS Desktop. Redlands, California: Environmental Systems Research Institute, Inc.; 2013. http://www.esri.com/arcgis/about-arcgis.

59. Magistratsabteilung 41-Stadtvermessung. Basic map of Vienna. 2011. https://www.data.gv.at/katalog/dataset/332be1f6-5791-43ae-9e37-90cc4 $8 \mathrm{e} 75 \mathrm{~d} 24$.

60. Hoffert H, Fitzka G, Stangl E, Lumasegger M. Projekt Grünraummonitoring Wien: Gesamtbericht. Vienna, Austria: Magistrat der Stadt Wien, Magistratsabteilung 22-Umweltschutz; 2008.

61. Magistratsabteilung der Stadt Wien MA 22-Umweltschutz. Begriffserklärung zum Grünraummonitoring. 2017. https://www.wien.gv.at/umwel tschutz/naturschutz/gruenraummonitoring/gruenraummonitoring-gloss ar.html. Accessed 29 Sept 2017.

62. Marks CA, Bloomfield TE. Home-range size and selection of natal den and diurnal shelter sites by urban red foxes (Vulpes vulpes) in Melbourne. Wildl Res. 2006;33:339-47.

63. Magistratsabteilung der Stadt Wien MA 23-Wirtschaft, Arbeit und Statistik. Statistisches Jahrbuch der Stadt Wien 2014. Vienna, Austria; 2014.

64. Heigl F, Horvath K, Laaha G, Zaller JG. Amphibian and reptile road-kills on tertiary roads in relation to landscape structure: using a citizen science approach with open-access land cover data. BMC Ecol. 2017;17:24.

65. Crawley MJ. The R Book 1. Auflage. Hoboken: Wiley; 2007.

66. Zuur AF, Hilbe JM, Leno EN. A Beginner's Guide to GLM and GLMM with R: a frequentist and bayesian perspective for ecologists. Newburgh: Highland Statistics Ltd; 2013.

67. R Development Core Team. R: A language and environment for statistical computing. Vienna, Austria; 2008. http://www.R-project.org. 